\title{
Rhinoclemmys nasuta (Boulenger 1902) - Large-Nosed Wood Turtle, Chocoan River Turtle
}

\author{
John L. Carr ${ }^{1,2}$ ANd Alan Giraldo ${ }^{2}$ \\ ${ }^{1}$ University of Louisiana at Monroe, Department of Biology and \\ Museum of Natural History, Monroe, Louisiana 71209-0520 USA [carr@ulm.edu]; \\ ${ }^{2}$ Universidad del Valle, Facultad de Ciencias, Departamento de Biología, Sección de Zoología, \\ Grupo de Investigación en Ecología Animal, A.A. 25360, Cali, Colombia [ecologia@univalle.edu.co]
}

SuMmary.-The large-nosed wood turtle, Rhinoclemmys nasuta (Family Geoemydidae), is a small to medium-sized aquatic turtle (carapace length to $228 \mathrm{~mm}$ ) found in a variety of northwestern South American water bodies, including small streams and rivers. It has a restricted distribution in the Chocoan rain forest of Pacific coastal Colombia and Ecuador. The species is known to have a primarily herbivorous diet, but small invertebrates are also eaten. Females lay one large egg per clutch. Adults exhibit female-biased sexual size dimorphism, and growth to maturity is protracted, with estimates varying from 12 to 14 years for males and females, respectively. Although its conservation status has not been studied thoroughly, the species is eaten on a subsistence basis, but it is not thought to be threatened by commercialization. Deforestation within the species range has not been studied with respect to its effect on this highly aquatic species. This species occurs in one protected area in Ecuador and may occur in others in Colombia.

Distribution. - Colombia, Ecuador. Confined to the Chocoan rainforest area in Pacific coastal drainages of northwestern Ecuador and western Colombia, and the middle and upper portion of the Caribbean-draining Río Atrato basin in northwestern Colombia.

Synonymy. - Nicoria nasuta Boulenger 1902, Geoemyda nasuta, Geoemyda punctularia nasuta, Rhinoclemmys punctularia nasuta, Rhinoclemmys nasuta, Callopsis punctularia nasuta, Callopsis nasuta.

SubSPECIES. - There are no recognized subspecies.

STATUS. - IUCN 2009 Red List Status: Near Threatened (LR/nt) (assessed 1996, needs updating); CITES: Not Listed; Colombian Red Data Book: Data Deficient.

Taxonomy. - Boulenger (1902) described nasuta as a species of Nicoria based on a small series from Esmeraldas Province, Ecuador. Subsequent taxonomic works considered this taxon as a species of Geoemyda (Siebenrock
1909; Mertens et al. 1934; Wettstein 1934) until Mertens (1954) treated it as a subspecies of Geoemyda punctularia. Although Medem (1962:279) considered it to be a discrete species based on his personal field experience, he continued

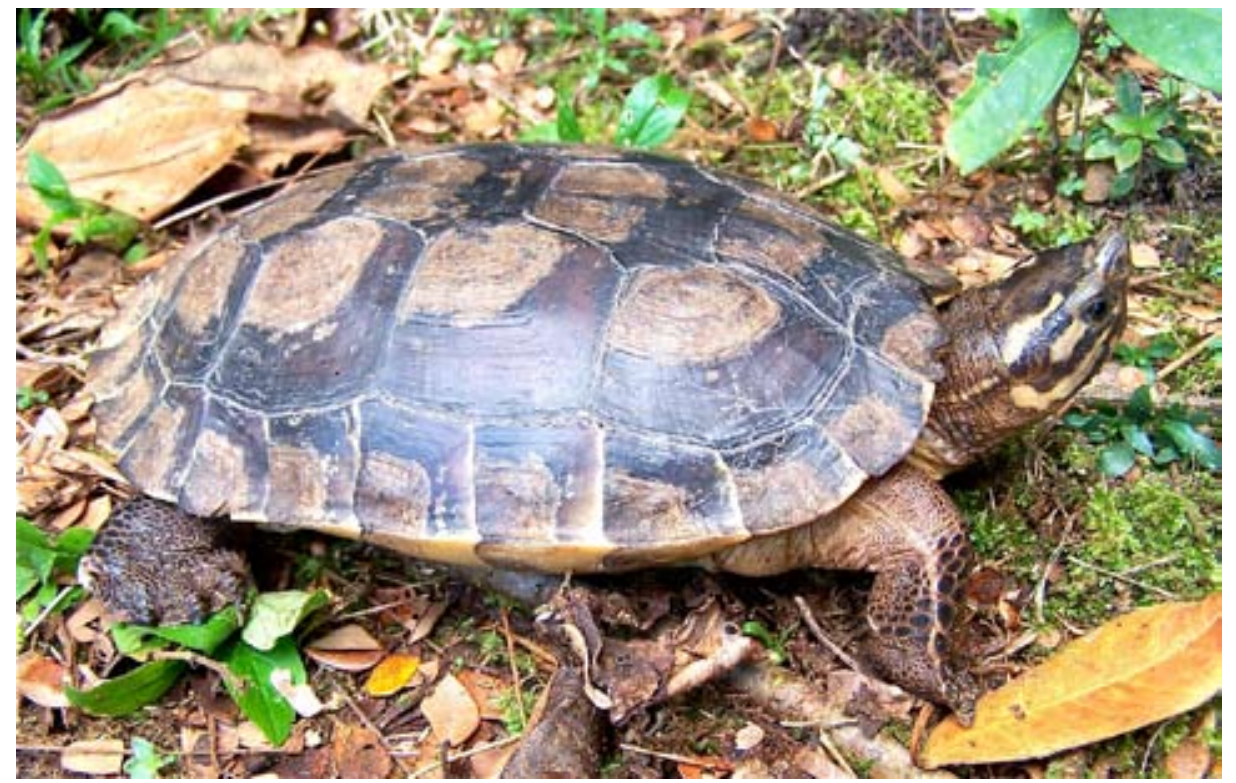

Figure 1. Adult female Rhinoclemmys nasuta from Isla Palma, Departamento del Valle, Colombia.Photo by José Vicente Rueda-Almonacid. 
to use the name Geoemyda punctularia nasuta throughout the text. In his revision of the genus Callopsis (a synonym of Rhinoclemmys), Ernst (1978) formally elevated it once again to species status. Since the publication of Smith(1978), it has been recognized universally as a full species in the genus Rhinoclemmys, and well established as distinct from $R$. punctularia and its sympatric congeners ( $R$. annulata and $R$. melanosterna). Although there is some geographic variation in shell proportions, there are no described subspecies (Ernst 1978). Based largely on morphological and allozyme data, Carr (1991) hypothesized $R$. nasuta to be the basal species in the genus. In a molecular phylogeny based on mitochondrial and nuclear genes, depending on

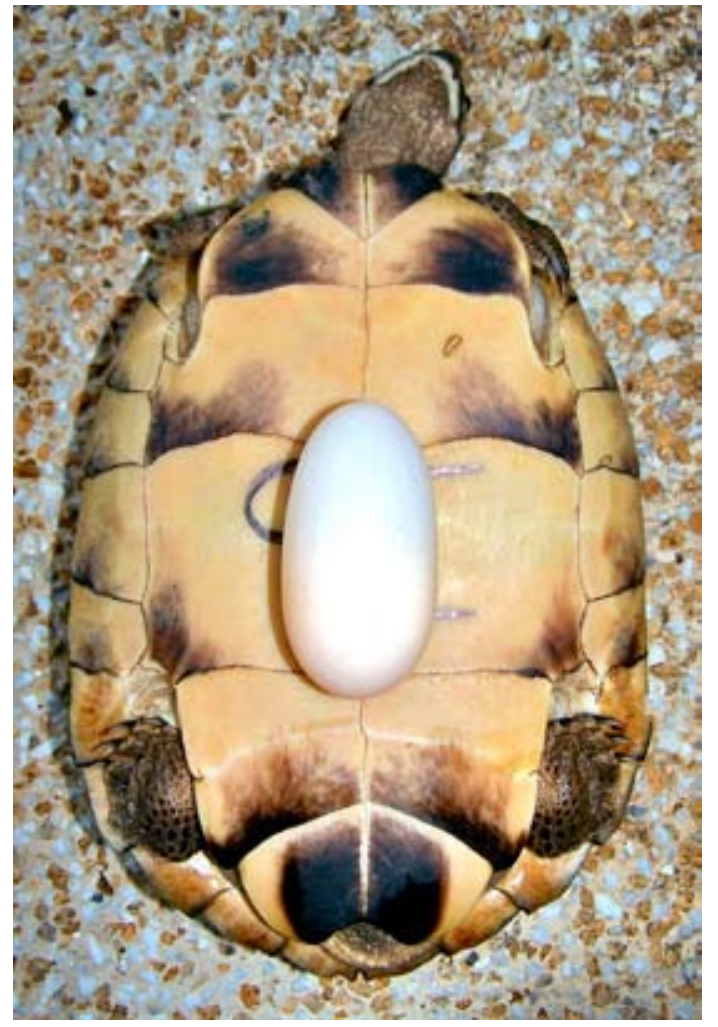

Figure 2. Female Rhinoclemmys nasuta with egg from Isla Palma, Departamento del Valle, Colombia. Photo by José Vicente RuedaAlmonacid.

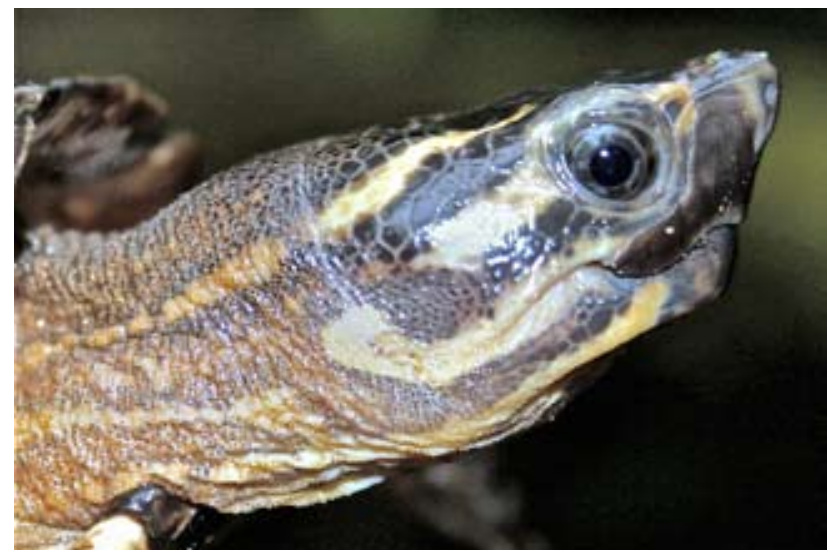

Figure 3. Female Rhinoclemmys nasuta from Isla Palma, Departamento del Valle, Colombia. Photo by Alan Giraldo. the type of analysis, the phylogenetic position of $R$. nasuta was unresolved, or poorly supported as sister to a clade of Rhinoclemmys including areolata ((diademata, punctularia) (funerea, melanosterna)) (Le and McCord 2008).

Description. - This is a small to medium-sized (to ca. $228 \mathrm{~mm}$ carapace length) species of Rhinoclemmys with an ovate and very depressed shell. The carapace is dark brown to black. Each plastral scute generally has a discrete dark blotch, with variably extensive, intervening light-colored areas between blotches. Ground color of the head is dark brown to black with a pale white or yellowish postorbital and supratemporal stripe. The skin of the posterior and lateral head is scaly, not smooth. The dark gular skin has light-colored, circular spots. This species is distinguished from all other Rhinoclemmys by the following combination of shell features: contact between humeral and axillary scutes is absent; there is contact between the lateral portion of the pectoral-abdominal seam and the ventral portion of marginal scute 5; the anterior margin of costal scute 2 contacts either marginal scute 4 or the marginal 4-5 seam; and the dorsal outline of marginal scute 5 is quadrangular.

Rhinoclemmys nasuta exhibits female-biased sexual size dimorphism in shell dimensions, with maximum CL of 228 and $196 \mathrm{~mm}$ in females and males, respectively (Medem 1962; Loaiza-Naranjo et al. 2006; Garcés et al. 2008). The same holds true for weight, with females averaging $772 \mathrm{~g}$, and males only $407 \mathrm{~g}$ (Loaiza-Naranjo 2006; Giraldo et al.
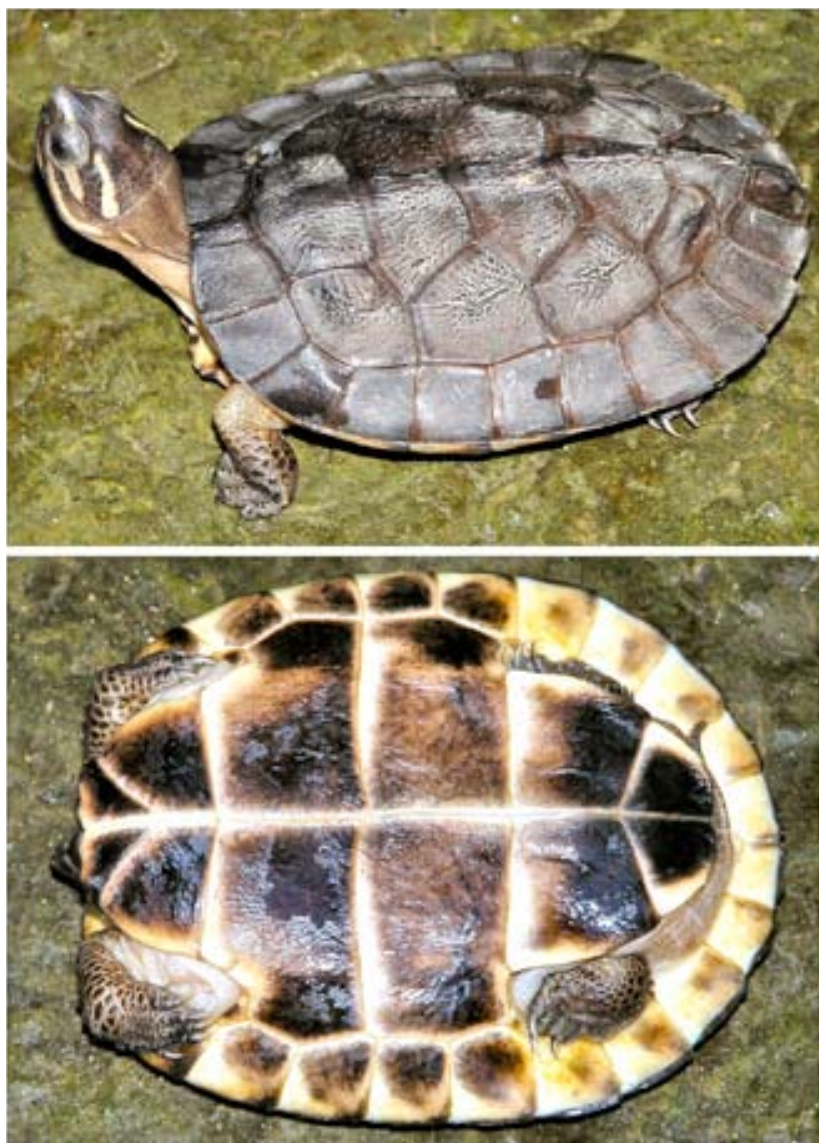

Figure 4. Near hatchling size Rhinoclemmys nasuta from Isla Palma, Departamento del Valle, Colombia. Photos by John L. Carr. 


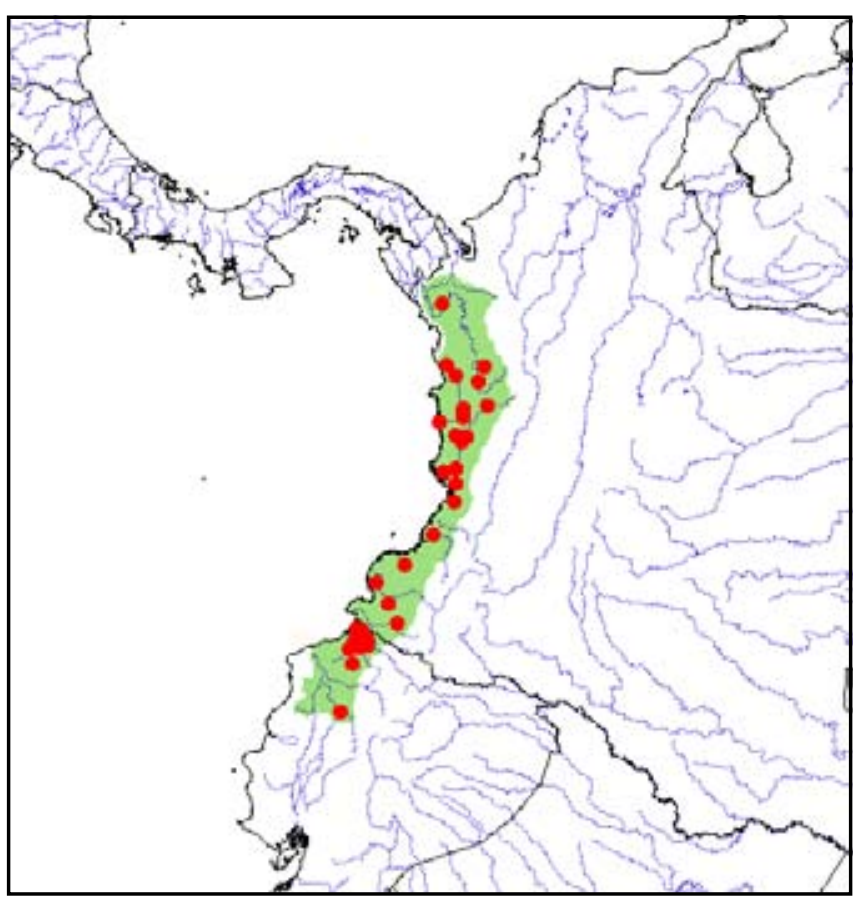

Figure 5. Distribution of Rhinoclemmys nasuta in Ecuador and Colombia, northwestern South America. Red points $=$ museum and literature occurrence records based on Carr and Almendáriz (1990), Iverson (1992), Vargas and Bolaños (2000), Castaño-Mora et al. (2004), and Ortega and Regalado-Sotelo (in press), plus more recent and authors' data; green shading = projected distribution based on GIS-defined hydrologic unit compartments (HUCs) constructed around verified localities and then adding HUCs that connect known point localities in the same watershed or physiographic region, and similar habitats and elevations as verified HUCs (Buhlmann et al., in press), and adjusted based on authors' data.

2007; Garcés 2008). The male shell is more elongate and narrow than that of the female, as well as averaging smaller in size, and in some male specimens, the plastron is slightly concave (Medem 1962; Ernst 1978, 1980). Males have a longer tail than females, with the vent opening posterior to the carapace margin (Ernst 1978, 1980). There is also variation in the growth rate between the sexes, with the growth rate estimated as $5.8 \mathrm{~mm} / \mathrm{yr}$ for juveniles, declining to $0.9 \mathrm{~mm} /$ yr for males and $-0.5 \mathrm{~mm} / \mathrm{yr}$ for large females, respectively (Pérez et al., in press).

Distribution. - This species is recorded from the Caribbean-drained middle and upper Río Atrato basin of northwestern Colombia, and from Pacific coastal drainages from the Río Baudó in Colombia south to the RíoEsmeraldas basin in Ecuador (Medem 1962; Carr and Almendáriz 1990; Castaño-Mora et al. 2004; Rueda-Almonacid et al. 2007). Erroneous localities in Ecuador and the type localities were discussed by Carr and Almendáriz (1990).

Habitat and Ecology. - Medem (1962) reported that this species lives in a variety of aquatic habitats, including large rivers, small rivers, creeks, and lagoons or lakes. It will apparently also enter brackish water. He considered it the most aquatic species of the genus, capable of swimming very fast. We have found individuals in 1st and 2 nd order streams (Carr and Almendáriz 1990; Loaiza-Naranjo 2006; Giraldo et al. 2007). The species inhabits areas of tropical wet forest on the coastal plain and piedmont up to $800 \mathrm{~m}$ altitude in Colombia (Castaño-Mora et al. 2004; Ortega and Regalado-Sotelo, in press), and up to $600 \mathrm{~m}$ altitude in Ecuador (Carr and Almendáriz 1990). In some places, streams in degraded, secondary forest are inhabited (Carr and Almendáriz 1990; Vargas and Bolaños 2000).

Based on reports from locals within the natural range, Medem (1962) reported clutches of one or two eggs, laid anytime during the year, but primarily between January and March; however, during dissections he found no more than a single egg in the months of November, December, and April. The number of enlarged ovarian follicles of various sizes led him to suggest that oviposition may occur throughout the year. His informants told him eggs may be laid on a beach (sandbar) or in the forest near the bank. Females were variously reported as not digging a nest or only a shallow hole and not covering the eggs with soil, although sometimes they did so with leaves (Medem 1962). It is estimated that $R$. nasuta requires ca. 12 years to reach the minimum size of sexual maturity for males (approximately $140 \mathrm{~mm} \mathrm{CL}$ ), and ca. 14 years for females (estimated as $160 \mathrm{~mm} \mathrm{CL}$; Pérez et al., in press).

Eggs are large and hard-shelled, white, elongate ellipsoids (Medem 1962). Three eggs he measured ranged between $35-39 \mathrm{~mm}$ in width and $67-70 \mathrm{~mm}$ in length.

The species is primarily herbivorous according to Medem (1962). He found stomach contents that contained aquatic plants, leaves, seeds, and fruits, though one specimen had eaten a grasshopper. Corredor-Londoño et al. (2007) reported stomach contents of leaves, seeds, and flowers in a single specimen. Based on analysis of 25 fecal samples from a population on Isla Palma, Colombia, this species 
feeds principally on seeds of Fabaceae and litterfall of Cecropiaceae, as well as animal matter consisting primarily of Hymenoptera and Odonata (Alegría et al. 2007; Giraldo et al. 2007).

Medem (1962) found trematodes in the stomach and nematodes in the intestines. Dyer and Carr (1990a) listed four species of digenetic trematodes of two families from specimens of $R$. nasuta collected in Ecuador: Octangioides tlacotalpensis (Angiodictyidae), and three in the Paramphistomidae: Nematophila grandis, Pseudocleptodiscus margaritae, and Pseudallassostoma heteroxenus. In addition, Dyer and Carr (1990b) reported two species of nematodes from R. nasuta in Ecuador: Falcaustra tikasinghi (Ascaridida) and Hedruris sp. (Spirurida).

Medem (1962) noted that Crocodylus acutus and Caiman crocodilus eat $R$. nasuta. He also reported finding a small specimen in the stomach of a $2 \mathrm{~m}$ long snake (Drymarchon corais melanurus).

Population Status. - Medem (1962) reported the species was abundant in the San Juan, Docampadó, and Baudó rivers in the Department of Chocó, Colombia. Based on a capture-recapture study of a population on the Pacific coast of Colombia with a reduced incidence of anthropogenic influence and no natural predators (Isla Palma, Bahía Málaga, $\left.3^{\circ} 53^{\prime} \mathrm{N}, 77^{\circ} 21^{\prime} \mathrm{W}\right)$, population size was estimated as $756 \pm$ 100 individuals with a male:female sex ratio of 1:1.3 (LoaizaNaranjo et al. 2006; Giraldo et al. 2007; Garcés 2008). For the same population, density was estimated as 1428 individuals per ha of stream (Garcés 2008). Recently, Garcés et al. (2008) found that the male-female sex ratio was the same in a population from a mainland locality with a high level of human intervention.

Threats to Survival. - Humans eat this species as a source of protein or use it in traditional medicinal practices in Colombia (Medem 1962; Castaño-Mora and Medem 2002; Galvis-Rizo and Corredor-Londoño 2006; Garcés 2008) and northwestern Ecuador (Carr et al., in prep.). They are also frequently kept as pets and their shells are used in the construction of decorative items (Corredor-Londoño et al. 2006; Galvis-Rizo and Corredor-Londoño 2006; Loaiza-Naranjo 2006; Corredor-Londoño et al. 2007; Garcés 2008).

Conservation Measures Taken. - Rhinoclemmys nasuta undoubtedly benefits from general measures against commercial scale collecting of wildlife for export in Colombia and Ecuador. It is not listed on the CITES Appendices, nor did it receive a rating in the IUCN/SSC Action Plan (IUCN 1989). This species is listed in the IUCN 2009 Red List as Lower Risk / Near Threatened (IUCN 2009). At the national level within Colombia, it has also been treated as Near Threatened (Rueda-Almonacid 2000; MMA 2002) or Data Deficient (Castaño-Mora and Medem 2002).

In Ecuador, this species is known from the CotacachiCayapas Ecological Reserve, and in Colombia it is possibly found in Sanquianga and Utría Natural National Parks. A locality in Machalilla National Park, Ecuador, which is outside the known range of $R$. nasuta, was noted by Cisneros-Heredia (2006) who erroneously attributed the record to Almendáriz and Carr (1992). Reserves and communal territories for indigenous Amerindians and populations of African descent also contain populations of this species in Ecuador and Colombia.

Conservation Measures Proposed. - A status survey throughout the species range would be desirable, but the species does not presently appear to be greatly threatened with extinction.Among the recommendations of action plans in Colombia are additional study of the biology of the species, environmental education activities to raise awareness of threats to turtle populations in general, and strengthening of enforcement activities related to protective legislation already in place (Castaño-Mora 2002; MMA2002; CorredorLondoño et al. 2006).

This species hardly ever enters the international pet trade, but several years ago one of us (JLC) noted importation of R. nasuta into the United States from Peru, which is a non-range country for this species. Trade officials should be vigilant for shipments of this species being "laundered" through countries that neighbor on range states.

Captive Husbandry. - Specimens maintained in captivity by Medem (1962) ate plantains and raw meat, but did not eat well and died within a couple of months. One specimen of Ecuadorian origin lived in captivity for 19 years (Carr, pers. obs.). When newly captured, specimens are relatively aggressive and defend themselves by biting, but after awhile they become more timid and do not attack other turtles (Medem 1962; Carr,pers.obs.).Along the central part of the Colombian Pacific coast, young specimens that are captured may be raised in captivity to be used later as food (Corredor-Londoño et al. 2007).

Current Research. - Observations on the subsistence use of $R$. nasuta and other species by rural inhabitants of northwestern Ecuador are in preparation for publication (Carr et al., in prep.). Analyses of genetic diversity and molecular characterization of a population of $R$. nasuta (Isla Palma, Bahía Málaga) using genetic markers and mitochondrial DNA sequencing are being developed (Molina et al. 2008; Castillo et al.2009).An analysis of spatial ecology, including movements (Pérez 2007), is in preparation for publication.

Acknowledgments. - We thank our colleagues for assistance in various ways: Ana Almendáriz, Mark Nielsen, John Simmons, Mike Ewert, J.V. Rueda-Almonacid, Carlos Galvis, German Corredor, and John Iverson. For field assistance we would like to thank: Magnolia Murcia, Claudia Restrepo, Carlos Ballesteros, Sergio Navarrete(Universidad Católica de Chile), José Cuellar,Jhonatan Loaiza, Cesar Ortiz, Bellineth Valencia, Mario Garcés, Andrés Quintero, Viviana Pérez, Jorge Alegría, and Julio Benítez. Work in Ecuador was conducted with permits from MAG. We thank the Dirección General Marítima (DIMAR) for permission to work on Isla Palma, and the lighthouse keepers, Sr. Ricardo, his son, and Iván Gutiérrez. Our studies of this species were financed in part by the National Science Foundation (BSR-8601094), Smithsonian Institution, the Linnaeus Fund of Chelonian Research Foundation, Turtle Research Fund of the ULM 
Foundation, Colciencias, the Universidad del Valle (Univalle), and the Grupo de Investigación en Ecología Animal of Univalle.

\section{LITERATURE CITED}

Alegría, J., Giraldo, A., CArr, J.L., and Pérez-Arteaga, J.V. 2007. Hábitos alimenticios de la tortuga Rhinoclemmys nasuta en Isla Palma - Pacífico colombiano. Libro Resúmenes. VII Simposio Internacional de Zoología, Topes de Collantes, Cuba.

Almendáriz, A. AND CARr, J.L. 1992. Amphibian and reptile list; January-February trip. In: Parker, T.A., III, and Carr, J.L. (Eds.). Status of Forest Remnants in the Cordillera de la Costa andAdjacent Areas of Southwestern Ecuador. Washington, DC: Conservation International, RAP Working Papers 2, pp. 128-130.

BOULENGER, G.A. 1902. Descriptions of new batrachians and reptiles from north-western Ecuador. Annals and Magazine of Natural History (7)9:51-57.

Buhlmann, K.A., Akre, T.S., Iverson, J.B., Karapatakis, D., MitTermeier,R.A.,GEORges,A.,Rhodin,A.G.J., VAN DiJK,P.P., AND GiBBons, J.W.In press. A global analysis of tortoise and freshwater turtle distributions withidentification of priority conservation areas. Chelonian Conservation and Biology 8(2): in press.

CARR, J.L. 1991. Phylogenetic analysis of the Neotropical turtle genus Rhinoclemmys Fitzinger (Testudines: Emydidae). Ph.D. Dissertation, Southern Illinois University.

CARR, J.L. AND AlmENDÁRIZ, A. 1990. Contribución al conocimiento de la distribución geográfica de los quelonios del Ecuador occidental. Politécnica 14(3):75-103.

Carr, J.L., Almendáriz, A., Simmons, J., And Nielsen, M. In prep. Subsistence hunting for turtles in northwestern Ecuador.

Castaño-Mora,O.V.(Ed.).2002.Libro Rojo de Reptiles deColombia. Bogotá, Colombia: Instituto de Ciencias Naturales-Universidad Nacional de Colombia, Ministerio del Medio Ambiente, and Conservación Internacional-Colombia, 160 pp.

Castaño-Mora,O.V. and Medem,F. 2002.Rhinoclemmys nasuta.In: Castaño-Mora, O.V. (Ed.). Libro Rojo de Reptiles de Colombia. Bogotá, Colombia: Instituto de Ciencias Naturales-Universidad Nacional de Colombia, Ministerio del Medio Ambiente, and Conservación Internacional-Colombia. p. 125.

Castaño-Mora, O.V., Cárdenas, G., Hernández, E.J., and CastroHerRera, F. 2004 . Reptiles en el Chocó biogeográfico. In: Rangel, J.O.(Ed.). Colombia Diversidad Biótica IV: El Chocó Biogeográfico/Costa Pacífica. Bogotá, Colombia: Universidad Nacional de Colombia, pp. 599-631.

CAstillo,L.,Giraldo,A.,ANd BarReto,G. 2009.Diversidadgenética de una población insular de la tortuga Hicotea Blanca (Rhinoclemmys nasuta) en Isla Pala, Bahía Málaga, utilizando microsatelites [trabajo de grado].Cali,Colombia:Universidad del Valle,Facultad de Ciencias Naturales y Exactas, Departamento de Biología.

Cisneros-Heredia, D.F. 2006. Turtles of the Tiputini Biodiversity Station with remarks on the diversity and distribution of the Testudines from Ecuador. Biota Neotropica 6(1):1-16.

Corredor-Londoño,G.,Amorocho,D., And Galvis-Rizo,C.A. 2006. Plan deAcción para la Conservación de las Tortugas Continentales y Marinas del Departamento del Valle de Cauca. Santiago de Cali, Colombia: Corporación Autónoma Regional del Valle del Cauca (CVC), $28 \mathrm{pp}$.

Corredor-Londoño, G., Kattan, G., Galvis-Rizo, C.A., and AmoROCHO, D. 2007. Tortugas del Valle del Cauca. Santiago de Cali, Colombia: Corporación Autónoma Regional del Valle del Cauca (CVC), 74 pp.
DYER, W.G. AND CARR, J.L. 1990a. Some digeneans of the Neotropical turtle genus Rhinoclemmys in Mexico and South America. Journal of the Helminthological Society of Washington 57:12-14.

Dyer, W.G. AND CARR, J.L. 1990b. Some ascaridid, spirurid, and rhabditid nematodes of the Neotropical turtle genus Rhinoclemmys in Mexico and South America. Journal of Parasitology 76:259-262.

ERnst, C.H. 1978. A revision of the Neotropical turtle genus Callopsis (Testudines: Emydidae: Batagurinae). Herpetologica 34:113-134.

ERnst, C.H. 1980. Rhinoclemmys nasuta. Catalogue of American Amphibians and Reptiles (264): 1.

Galvis-Rizo, C.A. AND CoRredor-Londoño, G. 2006. Evaluación del uso de las tortugas continentales en la costa Pacífica del Departamento del Valle del Cauca. Cali, Colombia: Fundación Zoológica de Cali, 13 pp.

GARCÉs, M.F. 2008. Estructura poblacional, variación morfométrica y dimorfismo sexual de Rhinoclemmys nasuta (Testudinata: Emydidae) en dos localidades del Pacífico vallecaucano [trabajo de grado]. Cali, Colombia: Universidad del Valle, Facultad de Ciencias Naturales y Exactas, Departamento de Biología.

GARCÉs,M.F., GIRALDO,A.,ANDCARR,J.L.2008.Population structure, morphometric variation and sexual dimorphism of Rhinoclemmys nasuta (Testudines: Geoemydidae) from two localities on the Colombian Pacific coast.VI Congreso Mundial de Herpetología. Manaus, Brasil.

Giraldo,A.,CARR,J.L.,LoAiZA-NARANJo,J.,PÉREZ-ARTEAGA,J.V., AND ALEGRía, J. 2007. Biology and ecology of Rhinoclemmys nasuta (Boulenger 1902) on the Pacific coast of Colombia. Fifth Annual IUCN Turtle Survival Alliance and IUCN Tortoise and Freshwater Turtle Specialist Group Conference. Atlanta, GA, USA.

IUCN. 1989. Tortoises and Freshwater Turtles: An Action Plan for their Conservation. Gland, Switzerland: IUCN, 47 pp.

IUCN. 2009. IUCN Red List of Threatened Species. Version 2009.2. <www.iucnredlist.org> . Downloaded on 18 November 2009.

IVERSON,J.B. 1992.ARevised Checklist withDistribution Maps of the Turtles of the World. Richmond, IN: Privately printed, 363 pp.

LE, M. AND McCord, W.P. 2008. Phylogenetic relationships and biogeographical history of the genus Rhinoclemmys Fitzinger, 1835 and the monophyly of the turtle family Geoemydidae (Testudines: Testudinoidea). Zoological Journal of the Linnean Society 153:751-767.

LoAiZA-NARANJo, J. 2006. Aspectos ecológicos de la tortuga Hicotea Blanca (Rhinoclemmys nasuta Boulenger, 1902) en Isla Palma, Bahía Málaga - Pacífico colombiano [trabajo de grado]. Cali, Colombia: Universidad del Valle, Facultad de Ciencias Naturales y Exactas, Departamento de Biología.

Loaiza-Naranjo, J., Giraldo, A., AND Carr, J.L. 2006. Tamaño población y dimorfismo sexual de Rhinoclemmys nasuta en Isla Palma, Bahía Málaga - Pacífico colombiano. In: Andrade, M.G., Aguirre, C.J., and Rodríguez-Mahecha, J.V. (Eds.). Segundo Congreso Colombianode Zoología. Conocer, Conservar y Utilizar Sosteniblemente la Fauna de Colombia. Libro de Resúmenes. Bogotá, Colombia: Panamericana Formas e Impresos S.A., p. 424.

MEdEM,F. 1962. La distribución geográfica y ecología de los Crocodylia y Testudinata en el Departamento del Chocó. Revista de la Academia Colombiana de Ciencias Exactas, Físicas y Naturales 11:279-303.

MerTens, R. 1954. Bemerkenswerte Schildkröten aus Sud-undZentralamerika. Die Aquarien-und Terrarien-Zeitschrift 7(9):239-242.

Mertens, R., Müller, L., AND Rust, H.T. 1934. Systematische Liste der lebenden Schildkröten. Blatter fur Aquarien-und Terrarienkunde 45:42-45, 59-67. 
MMA(Ministeriodel MedioAmbiente).2002.Tortugas Marinasy Continentales en Colombia: Programa Nacional Para la Conservación. Bogotá, Colombia: Ministerio del Medio Ambiente, 63 pp.

Molina, Y., Barreto, G., AND Giraldo, A. 2008. Implementación de la metodología de secuenciación de $\mathrm{ADN}$ mitocondrial (ADN $m t$ ) para el análisis genético de poblaciones de Rhinoclemmys nasuta (Testudines: Geoemydidae) [trabajo de grado]. Cali, Colombia: Universidad del Valle, Facultad de Ciencias Naturales y Exactas, Departamento de Biología.

Ortega,A. ANd Regalado-Sotelo, A. In press. Geographic Distribution: Reptilia, Testudines, Geoemydidae, Rhinoclemmys nasuta. Check List.

Pérez, J.V. 2007. Tasa de crecimiento y rango habitacional de $R h i$ noclemmys nasuta en Isla Palma - Pacífico colombiano [trabajo de grado]. Cali, Colombia: Universidad del Valle, Facultad de Ciencias Naturales y Exactas, Departamento de Biología.

Pérez, J.V., Giraldo, A., Carr, J.L., ANd Alegría, J. In press. Growth in Rhinoclemmys nasuta (Cryptodira: Geoemydidae) from Isla Palma on the Pacific coast of Colombia. Chelonian Conservation and Biology.

Rueda-Almonacid, J.V. 2000. Anfibios y reptiles amenazados de extinción en Colombia. Revista de la Academia Colombiana de Ciencias Exactas, Físicas y Naturales 23 (Suplemento Especial):475-497.

Rueda-Almonacid, J.V., CARr, J.L., Mittermeier, R.A., RodrígueZMahecha, J.V., Mast, R.B., Vogt, R.C., Rhodin, A.G.J., De La OsSa-VelÁsquEZ,J.,RUEDA,J.N.,AND MitTERMEIER,C.G.2007.Las Tortugas y los Cocodrilianos de los Países Andinos del Trópico. Bogotá, Colombia: Editorial Panamericana, Formas e Impresos,
Serie de Guías Tropicales de Campo No. 6, Conservación Internacional, $538 \mathrm{pp}$.

Siebenrock, F. 1909. Synopsis der rezenten Schildkröten, mit Berucksichtigung der in historischer Zeit ausgestorbenen Arten. Zoologischer Jahrbücher, Supplement 10:427-618.

Sмітн, H.M. 1978. The status of suppressed names and of Callopsis Gray (Reptilia: Testudines). Herpetological Review 9:93.

VARGAS, F. AND Bolaños, M.E. 2000. Anfibios y reptiles presentes en hábitats perturbados de selva lluviosa tropical en el Bajo Anchicayá, pacífico Colombiano. Revista de la Academia Colombiana de Ciencias Exactas, Físicas y Naturales 23 (Suplemento Especial):499-511.

WetTStEIn, O. 1934. Ergebnisse der osterreichischen biologischen Costa Rica-Expedition 1930: Die Amphibien und Reptilien. Sitzungsberichte der Mathematisch-Naturwissenschaftlichen Klasse der Kaiserlichen Akademie der Wissenschaften 143:139.

\section{Citation Format for this Account:}

CARR, J.L. AND GiRAldo, A. 2009. Rhinoclemmys nasuta (Boulenger 1902) - large-nosed wood turtle, Chocoan river turtle. In: Rhodin, A.G.J., Pritchard, P.C.H., van Dijk, P.P., Saumure, R.A., Buhlmann, K.A., Iverson, J.B., and Mittermeier, R.A. (Eds.). Conservation Biology of Freshwater Turtles and Tortoises: A Compilation Project of the IUCN/SSC Tortoise and Freshwater Turtle Specialist Group. Chelonian Research Monographs No. 5, pp. 034.1-034.6, doi:10.3854/crm.5.034.nasuta.v1.2009, http:// www.iucn-tftsg.org/cbftt/. 